\title{
Social Problems in Canadian Ice Hockey: An Exploration Through Film
}

Authors' contribution:

A) conception and design of the study

B) acquisition of data

C) analysis and interpretation of data

D) manuscript preparation

E) obtaining funding

\section{Curtis A. Fogel}

Lakehead University Orillia, Canada

ABSTRACT

\begin{abstract}
While celebrated as a highly popular sport in Canada, there are many social problems existing within and around Canadian ice hockey. These problems are often overlooked and rarely depicted in academic and journalistic research on sport. These social problems include, but are not limited to: extreme violence resulting in injuries and death, hazing rituals, multiple types of sexual violence, drug abuse, financial corruption, as well as various forms of prejudice and discrimination. Prompted by pop-cultural depictions in films, this paper further identifies and explores social problems in Canadian ice hockey revealing the realism embedded within various seemingly fictional films.

KEYWORDS social problem, violence, sexual violence, drug abuse, injury, death, hazing, exploration through film
\end{abstract}

\section{Introduction}

Despite not being Canada's most popular sport in terms of spectatorship and participation statistics, ice hockey is Canada's national winter sport and is widely considered to be part of its national identity and character. Internationally, it is the sport that Canada is known for due to its cold winters and international success in events such as the World Junior Hockey Championships and the Olympics. While much is celebrated about hockey in Canada, the sport has many dark sides that are often overlooked, ignored, and forgotten. Journalist Laura Robinson characterizes this with her call to Canadian parents:

"if you cherish the young boys in your life, you should keep them away from the game of hockey" (Elien 2010, 1).

Prompted by pop-cultural depictions of violence, hazing, sexual assault, and drug use in hockey films, this paper illuminates various social problems that currently exist Canadian ice hockey.

While much of the writing on Canadian hockey in academia and in the media is in celebration of the positive aspects of the sport, many scholars and journalists have looked at the darker social problems. Laura Robinson (1998) provides a detailed account of domestic violence and sexual violence perpetrated by players against young women, players against each other, and coaches against players. Adam Proteau (2011) examines the culture of on-ice violence in Canadian hockey and the injurious consequences that result from what he believes is an ever-increasing tolerance for such violence. Etue and Williams (1996) trace the history of marginalization of women in Canadian hockey and the ongoing battle for ice time, resources, and recognition. Fogel (2012) depicts public perceptions of violence in Canadian junior hockey, revealing a general distaste of spectators for extreme acts of injurious violence. Robidoux (2012) explores the First Nations hockey in Canada and somewhat refutes the monoptic view that it is a more "dangerous site where 
social problems such as alcohol consumption and violence are exacerbated" (p. 148). Valentine (2012) outlines the experiences of racism of players and coaches in the National Hockey League, with a particular interest in highlighting the processes by which non-Caucasian players are developed into violent enforcers on the ice. Rhind et al. (2013) examine violence in Canadian youth hockey from a human rights perspective, arguing that the United Nations Convention on the Rights of the Child (UNCRC) could be used as a legal framework fix problems social problems in the sport.

Using an unobtrusive, qualitative research methodology this paper explores pop-cultural depictions of various social problems in Canadian ice hockey films. Importantly, the aim of the paper is to show that the problems depicted are not the work of film-making fiction but rather, are serious social problems that exist within and surrounding Canadian ice hockey.

\section{Violence, Injury, and Death}

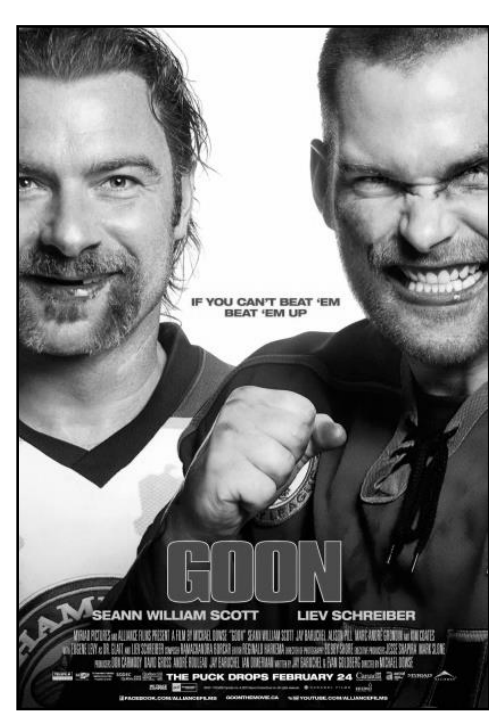

A recent Canadian film Goon (2011) provides a glimpse into the life of a hockey enforcer. An enforcer is a player whose role on a team is to fight players on opposing teams, make hard body checks, retaliate if a teammate is injured or threatened, and to energize the crowd with pure brutality. In an opening scene in Goon, a hockey spectator named Doug Glatt gets into a fight with a player who climbs into the stands. Glatt beats the hockey player much to the adoration of the crowd. After the game, Glatt gets a phone call from a local hockey coach asking him to play for his team. The problem is that Glatt is not a hockey player and must learn the basic skills of the sport.

Though Glatt cannot play hockey, he functions as an effective enforcer earning the nickname of Doug "the Thug" Glatt and is called up to play at a higher level for the Halifax Highlanders. His primary role on the team is to protect highly skilled, but afraid of being hit, teammate Xavier Laflamme particularly from an opposing player he fears named Ross "the Boss" Rhea. The film depicts a series of vicious on-ice fights involving players being knocked out and getting broken noses, amidst off-ice comedic scenes. The film culminates in a final game between the Highlanders and Rhea's St John's Shamrocks.

With the Highlanders down 2-0 in the third period, a fight between Doug "the Thug" Glatt and Ross "the Boss" Rhea ensues. Both exchange blows. Rhea's nose is broken, while Glatt seemingly breaks his ankle, yet the fight continues until Glatt delivers the final punch knocking Rhea unconscious. The Highlanders, energized by Glatt's fighting victory, go on to score three quick goals and win the game.

While Goon is intended to be a comedy, the realities that are depicted in the film are not. In one scene Rhea is shown swinging his stick and connecting with an opposing player's head, which bears a strong resemblance to an NHL incident in 2000. In R. v. McSorley (2000), professional hockey player Marty McSorley violently struck his stick against the head of an opposing player named Donald Brashear, and was convicted of assault with a deadly weapon. Four years later, another professional hockey player named Todd Bertuzzi appeared in Canadian courts for an incidence of violence in professional ice hockey $(R$. v. Bertuzzi 2004). In this incident, Todd Bertuzzi struck another player, Steve Moore, in the back of the head with his gloved fist, resulting in two broken vertebra and brain injuries that subsequently ended Moore's hockey career. Bertuzzi was given a conditional discharge on the grounds that he serve 80 hours of community service. While Goon does not fully reenact Bertuzzi's act of violence, the movie does include a press conference scene where Rhea becomes emotional in near replication of Todd Bertuzzi's tearful press conference following his suspension.

\footnotetext{
${ }^{1}$ Photo retrieved from: http://www.impawards.com/2012/goon_ver6.html.
} 
On-ice violence and the injuries, concussions, and even deaths that result are a serious issue in the sport. In 2009, Ontario Hockey League player Don Sanderson died following an on-ice fight in which his head struck the ice (Martino, 2009). In 2011, three NHL enforcers died from the reported effects of repeated concussions or brain trauma due to on-ice fighting (Branch, 2011). The three players - Derek Boogaard, Rick Rypien, and Wade Belak- played in a combined 945 National Hockey League regular season games yet scored a combined total of 20 goals over that span. They did, however, accumulate over 2000 penalty minutes and entered into fights hundreds of times. While Goon depicts violence in ice hockey in a comedic fashion, it remains a serious problem in the sport with grave consequences.

\section{Hazing}
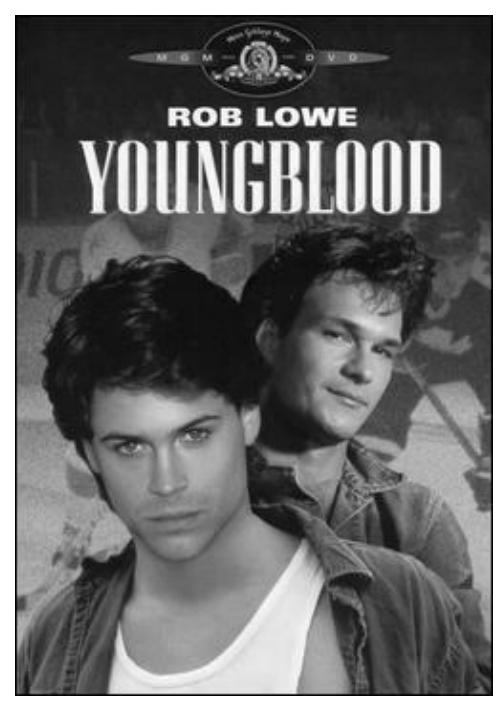

In a 1986 hockey film, Youngblood, depicts the struggles of a 17-year old named Dean Youngblood to fulfill his dream of playing in the National Hockey League. Youngblood is a highly skilled player but lacks the perceived toughness to play Canadian junior hockey, often considered to be a precursor to the NHL. A coach for the Hamilton Mustangs, however, takes a chance on Youngblood and puts him on the team. Upon joining the team, Youngblood is forced to endure a series of hazing rituals including underage drinking activities, sexual activities with an older woman while a teammate watches, and getting pinned down by teammates and having his pubic area shaven bare.

Youngblood struggles with the in-team violence, as well as the brutality of on-ice violence, and initially leaves the team to go back to his family farm. But, after an invigorating pep talk from his brother, he decides to rejoin the team and this time with a new aggressive demeanor. Youngblood goes on to guide his team to victory in the Memorial Cup, and as time expires in the game he challenges the tough guy on the opposing team to a fight involving sticks. This scene mirrors the real-life cases of $R$. v. Maki (1970) and R. v. Green (1971), two professional hockey players named Wayne Maki and Ted Green appeared in Canadian courts for an altercation involving swinging sticks at one another resulting in horrific injuries to the point of near death.

While on-ice violence remains a theme in Youngblood as with most hockey films, the depictions of hazing are of particular interest as another significant social problem in Canadian ice hockey. Hazing can be defined as:

"a rite of passage wherein youths, neophytes, or rookies are taken through traditional practices by more senior members in order to initiate them into the next stage of their cultural, religious, academic, or athletic lives" (Trota and Johnson, 2004, p. x).

The term hazing is often used synonymously with initiations, initiation rites, and initiation rituals. Hazing is often perceived as a voluntary part of male sports that is experienced by nearly all players (Woods, 2007). Hazing can have devastating consequences, e.g. the death of a men's volleyball player at St. Thomas University following hazing activities involving excessive alcohol consumption (Amirault, 2010). Hazing can also involve non-consensual physical and sexual violence (Fogel, 2013).

In 2011, Royal Canadian Mounted Police (RCMP) opened an investigation into an incident in the Manitoba Junior Hockey League (MJHL). According to reports, four rookie players were forced to walk around the team locker room with water bottle sets tied to their scrotums, while players threw towels onto the bottles to add extra weight (Turner, 2001). In total, 16 players received suspensions as well as the coach and

\footnotetext{
${ }^{2}$ Photo retrieved from: http://www.cduniverse.com/search/xx/movie/pid/1593342/a/youngblood.htm.
} 
assistant coach, but no criminal charges resulted. At least one of the victims has reported quit playing hockey following the incident.

In a previous unreported case, two men, a player and a team trainer, were charged after a series of hazing rituals performed on team rookies. Among other required sexual acts involved in this hazing incident, one of the rituals is described below:

"Scott did what he was told. These were men who could make or break his hockey career. They tied a string to his penis, and then suspended the pail over the hockey stick. Out came the pucks. They started to throw them into the pail. As the weight increased, it pulled heavily on the string. It hurt, but Scott endured until the string pulled off"' (Robinson, 1998, 67).

The themes in these cases, including the depiction in Youngblood, remain similar. Rookie players are forced into non-consensual sexual acts that are aimed to be humiliating and potentially quite painful.

\section{Sexual Violence}

The problem of sexual violence in Canadian ice hockey extends beyond hazing between players. Two other significant forms of sexual violence that currently plague Canadian ice hockey are:

1. Coaches sexually exploiting the players they coach;

2. Hockey players sexually assaulting women outside of the sport.

In 2012, one of the most widely publicized Canadian cases of sexual violence in Canadian youth sport resurfaced on the national newsstands. Graham James, a former Hockey News Man of the Year, was arrested on allegations that he engaged in long-term non-consensual sexual relations with youth Canadian hockey players he was coaching (Fogel and Sine, 2013). This arrest came on the heels of a previous jail sentence in 1997 for sexually assaulting three hockey players he had coached, which he later received a pardon for. Originally sentenced to two years, James has since had his sentence increased to five years.

The Graham James case has received widespread media attention in large part because of the celebrity status of his victims, two of which include former NHL players Theoren Fleury and Sheldon Kennedy. This prompted the documentary film Playing with Fire (2011) and Fifth Estate episode titled The Fall and Rise of Theo Fleury, based on Fleury's autobiography, and since adapted as a play, which depicts his experiences of sexual violence and his emotional and psychological struggles that ensure leading him to drug abuse and to the brink of suicide.

While these documentaries depict a very serious case of coaching-perpetrated sexual violence in Canadian sport, the issue is more significant than is revealed. There are hundreds of similar cases in the last several years in Canadian sport, and hockey in particular. In 2014, there have been several cases. Former RCMP officer and minor hockey coach John Davidson was arrested in Calgary on several counts of sexually assaulting young athletes (Judd, 2014). An Ottawa hockey coach named Kelly Jones plead guilty to sexual offences against nine children, inviting young players to his home to watch pornographic films before luring them into sexual activity (Cobb, 2014). Michael Kachanovsky, a coach with the Streetsville Minor Hockey Association, was arrested and charged with sexual assault and sexual exploitation (Criger, 2014). Toronto children's hockey coach Robert Dunford has been charged with two counts of sexual assault and two counts of sexual interference (Gero, 2014). Coaching-perpetrated sexual violence remains a significant yet largely ignored problem in Canadian ice hockey. 


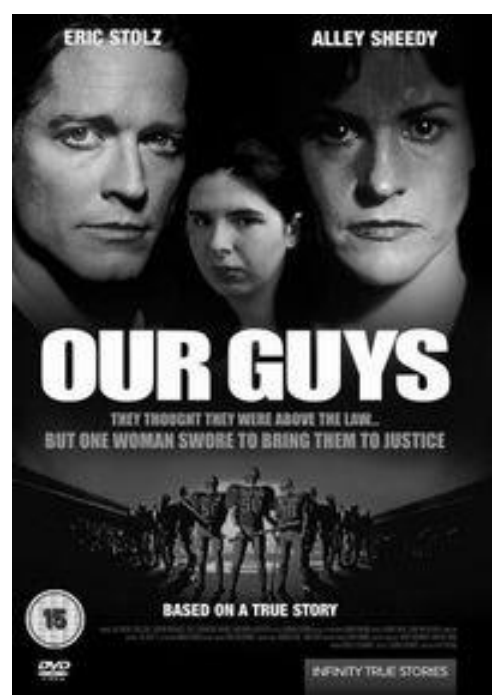

Athlete-perpetrated sexual violence against women is similarly pervasive. While films have focused on this issue in other sporting contexts, e.g. Our Guys (1999) focuses primarily on a gang-rape perpetrated by football and baseball players, the problem does not appear to be a focal point of hockey films. Though ignored in hockey films, the problem very clearly exists in Canadian ice hockey. In 2014, the University of Ottawa suspended its entire hockey program indefinitely following allegations of several team members gang sexually assaulting a woman while the team was on a road trip playing at Lakehead University in Thunder Bay (Bradshaw, 2014). In 2013, Brock University hockey goalie Mark Yetman received a sentence of three years in prison following the sexual assault of a sleeping woman. This was Yetman's third conviction for sexual assaults against women (Walter, 2013). In 2012, three players for the Sault St. Marie Greyhounds of the Ontario Hockey League were arrested following allegations of a gang sexual assault of a woman (Ruicci, 2012). Again, these are just a small sample of recent cases illustrating a much larger issue of athlete-perpetrated sexual violence against women in Canadian ice hockey.

\section{Drug Abuse}

While focused on child sexual abuse, the two documentaries Playing with Fire and the Fall and Rise of Theo Fleury previously discussed also explore the problem of drug abuse in Canadian hockey. The problem of alcohol abuse and the abuse of other drugs in hockey is thoroughly depicted in the hockey film Gross Misconduct (1993), alongside typical themes of violence on and off the ice.

Gross Misconduct traces the turbulent life and death of former NHL enforcer Brian "Spinner" Spencer. Following the death of his father in a RCMP shootout, Spencer turns to alcohol and other drug use to as his NHL career begins to derail. In his mid-20s, Spencer is sent down to the hockey minor leagues. He quits the team opting to move to Florida, where he is arrested for murder in a cocaine and prostitution related death. Spencer is found not guilty, but shortly thereafter he is shot and killed following a cocaine purchase.

In March of 2014, junior hockey player Terry Trafford was found dead in his SUV, having committed suicide following the suspension from his team due to drug use and other team rule violations (Seidel, 2014). Also in 2014, Tampa Bay Lightning forward Ryan Malone was arrested on charges of cocaine possession and driving under the influence (Macramalla, 2014). NHL enforcer Derek Boogaard was found to have died from an accidental overdose of alcohol and prescription painkillers (Branch, 2011). Bob Probert struggled with alcohol and cocaine addictions through much of his NHL career and died at 45 years old of apparent heart failure (Duhatschek, 2012). Many hockey players struggle with drug addictions, often with grave consequences.

\section{Conclusion}

Hockey films and documentaries provide a brief glimpse into the darker sides of the sport, such as issues of violence, catastrophic injuries, hazing, sexual violence, and drug abuse. These remain only some of the issues. There are many other social problems existing within the sport that have received much less attention in dramatized media but are nonetheless very present in Canadian ice-hockey such as: homophobia, racism, domestic violence, performance-enhancing drug use, impaired driving, financial corruption, matchfixing, and even murder-for-hire, e.g. NHL player Mike Danton was sentenced to 90 months in prison for conspiracy to commit murder.

\footnotetext{
${ }^{3}$ Photo retrieved from: http://glenridgerapemovie.blogspot.ca.
} 


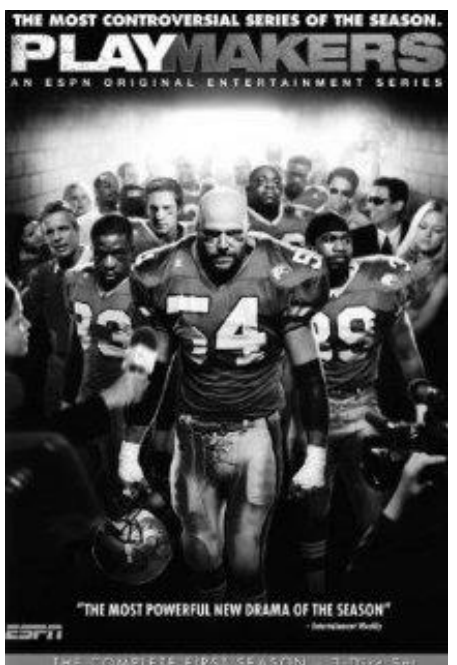

Hockley films have fallen short of depicting these serious social problems. In 2003 ESPN released a series titled Playmakers, which provided a fictional account of life on and off the field of professional football, providing an interesting glimpse into the similar social problems of American football. The show depicted various acts of crime and deviance in American football such as: injurious violence on the field, steroid use, painkiller use, illicit drug use, night club violence, domestic violence, homophobia, and eating disorders. The National Football League (NFL) league office claimed that the show was a gross misrepresentation of life in the NFL and successfully put pressure on ESPN to cancel it (Rovell, 2004). While these depictions might have been different from the image that the NFL would like to portray of the life of American football players, there is evidence that suggests that the storylines were based on real-life events occurring in and around NFL football. While cancelled after one season, the show revealed the power of mass media representations, such as television and film, to inspire public recognition of social problems in football.

In contrast to the critical edge of Playmakers, hockey films tend to glamorize certain social problems such as fighting, injurious violence, and dangerous masculinities, while normalizing other social issues such as hazing and sexual violence. Simultaneously, the hockey film genre appears to ignore ongoing problems of sexual assaults perpetrated by coaches against athletes, sexual assaults perpetrated by athletes against women, domestic violence perpetrated by athletes against women, and many other very serious social problems. Much more work must be done to illuminate and explore the interconnections between these problems by filmmakers and academic scholars alike.

\section{REFERENCES}

Amirault, C. (2010). "STU Officials Investigate Circumstances Surrounding Death." News 95.7. November 3. http://www.news957.com/2010/11/03/stu-officials-investigate-circumstances-surrounding-death/.

Bradshaw, J. (2014). “University of Ottawa Men's Hockey Team Suspended Over Alleged Sex Assault.” The Globe and Mail. March 3. http://www.theglobeandmail.com/news/national/university-of-ottawa-suspends-hockey-team-overserious-misconduct/article17201525/.

Branch, J. (2011). "Hockey Players' Deaths Pose a Tragic Riddle." The New York Times. September 1. http://www.nytimes.com/2011/09/02/sports/hockey/deaths-of-three-nhl-players-raises-a-deadly-

riddle.html?pagewanted=all\&_r=0.

Cobb, C. (2014). "Hockey Coach Kelly Jones Admits to Sexually Abusing Children." Ottawa Citizen. April 6. http://www.ottawacitizen.com/news/Hockey+coach+Kelly+Jones+admits+sexually+abusing+children/9710363/story.ht $\mathrm{ml}$.

Criger, E. (2014). "Streetsville Hockey Coach Arrested in 90s Sexual Assault." City News Toronto. May 7. http://www.citynews.ca/2014/05/07/streetsville-hockey-coach-arrested-in-90s-sexual-assault/.

Duhatschek, E. (2012). "Former NHL Tough Guy Bob Probert Dead at Age 45." The Globe and Mail. August 23. http://www.theglobeandmail.com/sports/former-nhl-tough-guy-bob-probert-dead-at-age-45/article569025/.

Elien, S. (2010). "Link Between Hockey and Rape Studied.” The Straight. May 12. http://www.straight.com/news/linkbetween-hockey-and-rape-studied.

Etue, E., \& Williams, M.K. (1996). On the edge: Women making hockey history. Toronto: Second Story Press.

Fall and Rise of Theo Fleury. (2009) The Fifth Estate. Canadian Broadcasting Company.

Fogel, C. (2012). Public responses to violence in Quebec junior hockey. Sport Science Review, 21(5), $173-182$.

Fogel, C. (2013). Game-Day gangsters: Crime and Deviance in Canadian Football. Edmonton, AB: Athabasca University Press.

\footnotetext{
${ }^{4}$ Retrieved from: http://www.imdb.com/title/tt0375411/.
} 
Fogel, C, \& Sine, C. (2013). Public perceptions of the legal handling of sexual violence in Canadian youth sport, International Law Research, 2: 96-101.

Gero, A. (2014). "Toronto Man Arrested and Charged with Sexually Assaulting Children.” Newstalk 1010. May 23. http://www.newstalk1010.com/news/2014/5/23/toronto-man-arrested-and-charged-with-sexually-assaultingchildren/print/.

Goon. (2011). Film directed by Michael Dowse. Alliance Films Canada.

Gross Misconduct. (1993). Film directed by Atom Egoyan. Canadian Broadcasting Company.

Judd, A. (2014). "Former RCMP Officer, Minor Hockey Coach, Charged with Sexual Assault of Minors." Global News Toronto. March 7. http://globalnews.ca/news/1193774/rcmp-to-announce-arrest-of-man-in-connection-to-8-historicalsex-assaults/.

Macramalla, E. (2013). "Ryan Malone's Arrest and His Legal Future." TSN. April 13. http://www.tsn.ca/nhl/story/?id=449282.

Martino, A. (2009). “Tragic Death of Club Player Don Sanderson Forces Hockey World to Question Violence”. New York Daily News. January 19. http://www.nydailynews.com/sports/hockey/tragic-death-club-player-don-sandersonforces-hockey-world-question-violence-article-1.422210.

Playing with Fire. (2011). Film directed by Larry Day and Matt Embry. HBO Canada.

Playmakers. (2003). Created by John Eisendrath. ESPN Entertainment.

Proteau, A. (2011). Fighting the good fight: Why on-ice violence is killing hockey. Mississauaga, ON: Wiley.

R. v. Bertuzzi, [2004] B.C.J. 2692.

R. v. Green, [1971], 1 O.R. 591.

R. v. Maki, [1970] 16 D.L.R. (3d) 137.

R. v. McSorley, [2000] B.C.J. 1993.

Rhind, D., Cook, E., and Dorsch, K.D. (2013). Looking at youth hockey from a human rights perspective, Sport and Society, 16(3), 254-266.

Robidoux, M. (2012). Stickhandling through the margins: First Nations hockey in Canada. Toronto: University of Toronto Press.

Robinson, L. (1998). Crossing the line: Sexual harassment and abuse in Canada's national sport. Toronto: McClelland and Stewart.

Rovell, D. (2004). "NFL Reaction to Series a Factor in Cancellation." ESPN. February 4. http://espn.go.com/gen/news/2004/0204/1727165.html.

Ruicci, P. (2012). "Greyhound Players Charged with Sexual Assault.” Toronto Sun. August 26. http://www.torontosun.com/2012/08/26/players-on-ohls-greyhounds-accused-of-sex-assault.

Seidel, J. (2014). "The Sudden, Silent, Tragic Exit of Terry Trafford." USA Today. March 23. http://www.usatoday.com/story/sports/hockey/2014/03/23/terry-trafford-death/6803401/.

The Rise and Fall of Theo Fleury (2010). The Fifth Estate. Canadian Broadcasting Corporation.

Trota, B., \& Johnson, J.. 2004. A brief history of hazing. In Making the Team: The Inside World of Sport Initiations and Hazing edited by Jay Johnson \& Margery Holman. Toronto: Canadian Scholar's Press. Pp. x-xvi.

Turner, R. (2011). "Hazing Victim had Water Bottles Tied to Genitals." Winnipeg Free Press. October 26. http://www.winnipegfreepress.com/breakingnews/Hazing-victim-had-water-bottles-tied-to-genitals-mother-

132648138.html.

Valentine, J. (2012). New racism and old stereotypes in the National Hockey League. In Race and Sport in Canada edited by Janelle Joseph, Simon Darnell, and Yuka Nakamura. Toronto: Canadian Scholars' Press.

Walter, K. (2013). “Goalie Gets Three Years for Third Sexual Assault.” St. Catherine's Standard. April 10. http://www.stcatharinesstandard.ca/2013/04/10/goalie-gets-three-years-for-third-sexual-assault.

Woods, R. (2007). Social issues in sport. Champaign, IL: Human Kinetics.

Youngblood. (1986). Film directed by Peter Markle. MGM Entertainment Company.

AUTHOR'S ADDRESS:
Curtis A. Fogel

Associate Professor of Criminology

Lakehead University Orillia

500 University Ave, Orillia

ON L3V 0B9, Canada

Email: cafogel@lakeheadu.ca 